\title{
Crop Establishment Methods and Weed Management Practices Affects Crop Growth, Yield, Nutrients Uptake and Weed Dynamics in Wheat
}

\author{
Ravi Prakash Singh ${ }^{1}$, S. K. Verma ${ }^{1}$ and Sushil Kumar ${ }^{1,2^{*}}$
}

${ }^{1}$ Dept. of Agronomy, Institute of Agricultural Sciences, Banaras Hindu University, Varanasi, Uttar Pradesh (221 005), India

${ }^{2}$ ICAR-Central Arid Zone Research Institute, Regional Research Station, Kukma, Bhuj, Gujarat (370 105), India

\section{Corresponding Author}

Sushil Kumar

e-mail: sushilangrau@gmail.com

\author{
Article History \\ Manuscript No. AR1812 \\ Received in $11^{\text {th }}$ May, 2017 \\ Received in revised form $29^{\text {th }}$ May, 2017 \\ Accepted in final form $7^{\text {th }}$ June, 2017
}

\begin{abstract}
The field experiment was conducted during winter (rabi) of 2014 and 2015 at Agricultural Research Farm, Institute of Agricultural Sciences, BHU, Varanasi. The experiment was conducted with twenty four treatment combinations consisting of four crop establishment methods in wheat viz., conventional tillage (CT) no-residue, CT with residue, zero tillage (ZT) no residue, ZT with residue as main plots and six weed management practices viz., weedy check, weed free, mesosulfuron $\left\{12 \mathrm{~g}\right.$ a.i. ha ${ }^{-1}$ at 30 days after sowing (DAS) $\}$ followed by $(f b)$ one hand weeding at $45 \mathrm{DAS}$, metsulfuron ( $4 \mathrm{~g}$ a.i. ha ${ }^{-1}$ at $\left.30 \mathrm{DAS}\right) \mathrm{fb}$ one hand weeding at $45 \mathrm{DAS}$, clodinafop+metsulfuron $\left(60+4 \mathrm{~g}\right.$ a.i. ha ${ }^{-1}$ at 30 DAS) and mesosulfuron+iodosulfuron $\left(12+2.4 \mathrm{~g}\right.$ a.i. ha ${ }^{-1}$ at $\left.30 \mathrm{DAS}\right)$ as sub plots in split-plot design with three replications, to evaluate the influence of crop establishment methods and weed management practices on crop growth, yield, nutrients uptake and weed dynamics. Results showed that ZT with residue recorded the lowest weeds density and dry weight, nutrients depletion by weeds and the highest weed control efficiency (WCE). However, CT with residue adjudged superior with respect to crop growth parameters, yield, and nutrients uptake by crop. Among herbicidal treatments, mix application of mesosulfuron+iodosulfuron recorded significantly lowest weeds density and dry weight and nutrients depletion by weeds and also recorded maximum WCE, plant height, number of tillers, crop dry weight, leaf area index (LAl), chlorophyll content, yield, and nutrients uptake over rest of the herbicidal treatments. The interaction between crop establishment methods and weed management practices was found to be significant only for grain and straw yield.
\end{abstract}

Keywords: Herbicides, crop residue, weed control efficiency, yield, crop establishment

\section{Introduction}

Wheat [Triticum aestivum (L.) emend. Fiori and Paol] occupies prime position among the food crops of the world. Introduction of high yielding dwarf genotypes of crop, increased fertilizers, irrigation and herbicides use coupled with scientific research have led India to the prestigious position in the world in wheat production. In India, wheat production has increased from $11 \mathrm{mt}$ during 1960 to $89 \mathrm{mt}$, covering an area of 29 mha with the average productivity of $2872 \mathrm{~kg} \mathrm{ha}^{-1}$ during 2014. The high nutrients and water requirement along with less competitive nature of high yielding dwarf varieties have provided conducive environment for increased weed infestation, which poses real challenge for successful wheat cultivation (Singh et al., 2015). Weeds compete with crops for water, nutrients and other growth factor, and in absence of an effective weed control measures, weeds remove considerable quantity of applied nutrients resulting in higher loss of yield and condition becomes severe under the scarcity of these resources (Sharma and Singh, 2011).
Now-a-days, herbicides use for weed control in wheat is becoming increasingly popular because traditional methods used for weed control are time-consuming, labour-intensive and cumbersome. Farmers generally use herbicides for weed control in wheat which has monotonous mode of action and continuous use of such type of herbicide has caused a shift in weed flora in favour of some broad-leaf weeds (Singh, 2007). Therefore, herbicides use patterns need to be rationalized in such a way that problem associated with such type of use pattern can be avoided in the future. Herbicide use has increased in both conventional and zero tillage systems because it provides effective and economical weed control, increases yield and saves labor, which has become more scarce and expensive (Rao et al., 2007). Singh et al. (2015) reported the application of herbicides significantly reduced density and dry biomass of total weeds over weedy check in wheat crop.

Tillage is the basic and most important requirement of crop production. The efficiency of input use viz. water, fertilizers, herbicides and others depends on tillage and crop establishment practices (Monsefi et al., 2016). Zero- 
tillage technique is an ecological approach for soil-surface management and seed-bed preparation, resulting in less input energy, less weed problem, better crop-residue management, enhances timeliness of wheat establishment and higher or equal yield (Jain et al., 2007). Zero till sowing in standing stubbles and after partial burning reduced the infestation of both categories of weeds as compared to conventional tillage as rice straw acted as mulch, due to less soil disturbance and loss of viability due to high temperature generated during burning (Brar and Walia, 2009). Mishra et al. (2005) reported lower population and dry matter of weeds under zero tillage as compared to conventional tillage.

Literature indicates that many research studies have been undertaken across the globe on different aspects of tillage practices and herbicides molecule in wheat crop. However, very few studies so far has been undertaken in wheat involving crop establishment methods and herbicides with or without residue management generally in world and particularly in eastern part of Uttar Pradesh. So, a thorough study was needed to understand how the crop establishment practices with or without residue and herbicides affect crop growth, yield, nutrients uptake and weed dynamics. Accordingly, this study was planned to understand the impact of different tillage practices with or without residue management and herbicides crop growth, yield, nutrients uptake and weed dynamics in wheat.

\section{Materials and Methods}

The field experiment was conducted during winter (rabi) season of 2014 and 2015 at Agricultural Research Farm, Institute of Agricultural Sciences, Banaras Hindu University, Varanasi $\left(25^{\circ} 18^{\prime} \mathrm{N}\right.$ latitude, 830.' E longitude and altitude of $129 \mathrm{~m} \mathrm{MSL}$ ). The soil of the experimental field was sandy clay loam in texture, with slightly alkaline in reaction $\mathrm{pH}$ 7.8). It was moderately fertile, being low in available organic carbon $(0.43 \%)$, available nitrogen $\left(206.2 \mathrm{~kg} \mathrm{ha}^{-1}\right)$, and available phosphorus (19.2 $\mathrm{kg} \mathrm{ha}^{-1}$ ) and potassium (238.2 $\left.\mathrm{kg} \mathrm{ha}^{-1}\right)$. Average values recorded for soil properties were bulk density $\left(1.42 \mathrm{~g} \mathrm{~cm}^{-1}\right)$, particle density $\left(2.62 \mathrm{~cm}^{-1}\right)$, filed capacity $(19.57 \%)$, permanent wilting point $(4.31 \%)$ and EC (0.181 dSm-1).

Total twenty four treatment combinations of four crop establishment methods viz. conventional tillage (CT) noresidue, CT with residue, zero tillage (ZT) no-residue and $\mathrm{ZT}$ with residue as main plots and six weed management practices viz., weeded check, weed free (Weeds were removed with the help of hand hoe during entire crop period), mesosulfuron (12 g a.i. ha ${ }^{-1}$ at 30 DAS) $f b$ one hand weeding at 45 DAS, metsulfuron ( $4 \mathrm{~g}$ a.i. ha-1 at $30 \mathrm{DAS}$ ) $\mathrm{fb}$ one hand weeding at 45 DAS, clodinafop+metsulfuron (60+4 g a.i. ha- $\mathrm{h}^{-1}$ at $\left.30 \mathrm{DAS}\right)$ and mesosulfuron+iodosulfuron $\left(12+2.4 \mathrm{~g}\right.$ a.i. $\mathrm{ha}^{-1}$ at $\left.30 \mathrm{DAS}\right)$ as sub plots were tested in split-plot design with three replications. CT plots were ploughed by tractor-drawn disc plough followed by planking and ZT plots were left undisturbed. Wheat variety 'HUW 234' was sown with different crop establishment methods at row distance of $22.5 \mathrm{~cm}$ by opening slits with zero-till-drill machine. Previous season rice straw was applied @ $6 \mathrm{t} \mathrm{ha}^{-1}$ as mulch material in the respective treatments. All the herbicides were applied as post emergence 30 days after sowing (DAS) with the help of foot sprayer fitted with flat fan nozzle. The spray volume of 400 litres water ha-1 was used. Half amount of nitrogen and full dose of phosphorus and potash was applied as basal at the time of sowing, $1 / 4$ part of nitrogen was top dressed after first irrigation and remaining $1 / 4$ part of nitrogen was top dressed at spike initiation stage. The nitrogen $(\mathrm{N})$, phosphorus $(\mathrm{P})$ and potassium $(\mathrm{K})$ were applied in the form of urea, single super phosphate and murate of potash, respectively. Three irrigations were given to crop at critical stages of crop growth (CRI-21 DAS, before spike initiation-75 DAS and grain filling 90 DAS).

An area of $0.25 \mathrm{~m}^{2}$ was randomly selected in each plot at 3 spots by placing a quadrate of $0.5 \times 0.5 \mathrm{~m}^{2}$ for weed species count and wed density. The collected weeds were first sundried and then kept in an electric oven at $60^{\circ} \mathrm{C}$ till the weight become constant, and dry weight was expressed as $\mathrm{g} \mathrm{m}^{2}$. As wide variation existed in data, number and dry weight of weeds were transformed through squire-root $\sqrt{ }(x+0.5)$ methods before analysis of variance. Wheat was harvested manually, but was threshed by power operated thresher. The nutrients depletion by weeds worked out at 80 days after sowing. Plant height, crop dry weight, tillers per running meter and yield of crop was recorded at harvest. Nutrients content in crop were determined as per the standard procedures at harvest and uptake values were worked out. The collected data were analysed statistically by following analysis of variance procedure described by Gomez and Gomez (1984).

\section{Results and Discussion}

\subsection{Density and dry weight of weeds}

Crop establishment methods significantly influenced the density and dry weight of weeds (Table 1). The maximum density and dry weight of all types of weeds was recorded under CT no-residue. ZT with residue recorded lowest density and dry weight of all types of weeds followed by CT with residue, $\mathrm{ZT}$ no-residue and $\mathrm{CT}$ no-residue, respectively. The less weed problem under ZT system was due to less soil disturbance as a result weed a seed present in lower soil layer fails to germinate due to mechanical impedance (Singh et al., 2015). Wheat sown with zero till drill exhibited significantly lower density and dry weight of weeds than conventional method, however, it was found to be nonsignificant with reduced tillage (Shyam et al., 2014). Among herbicidal treatments, mixture application of mesosulfuron+ iodosulfuron recorded significantly lowest density and dry weight of all types of weed than metsulfuron $f b$ one hand weeding at 45 DAS and mesosulfuron $f b$ one hand weeding at 45 DAS but it was at par with clodinafop+metsulfuron. Effective control of complex weed flora in wheat with tankmix application of herbicides was also reported by Bharat et al. (2012 and Yadav and Dixit (2014). Excellent control of complex weed flora in wheat was also observed with the tank mix application of mesosulfuron-methyl + iodosulfuron- 
Table 1: Effect of crop establishment methods and weed management practices on weed density, weed dry weight and weed control efficiency at 80 DAS in wheat

\begin{tabular}{|c|c|c|c|c|c|c|c|c|c|c|c|c|}
\hline \multirow{2}{*}{$\begin{array}{l}\text { Treatments } \\
\text { Crop estab- } \\
\text { lishment } \\
\text { methods }\end{array}$} & \multicolumn{2}{|c|}{$\begin{array}{c}\text { Grassy weed } \\
\left(\text { No. } \mathrm{m}^{-2}\right)\end{array}$} & \multicolumn{2}{|c|}{$\begin{array}{c}\text { Broad leaf } \\
\left(\text { No. } \mathrm{m}^{-2}\right)\end{array}$} & \multicolumn{2}{|c|}{$\begin{array}{l}\text { Sedges } \\
\left(\text { No. } \mathrm{m}^{-2}\right)\end{array}$} & \multicolumn{2}{|c|}{$\begin{array}{c}\text { Minor weed } \\
\left(\text { No. } \mathrm{m}^{-2}\right)\end{array}$} & \multicolumn{2}{|c|}{$\begin{array}{l}\text { WCE } \\
(\%)\end{array}$} & \multicolumn{2}{|c|}{$\begin{array}{c}\text { Weed dry } \\
\text { weight (kg } \\
\left.\mathrm{ha}^{-1}\right)\end{array}$} \\
\hline & 2014 & 2015 & 2014 & 2015 & 2014 & 2015 & 2014 & 2015 & 2014 & 2015 & 2014 & 2015 \\
\hline $\begin{array}{l}\text { Conventional } \\
\text { tillage-no } \\
\text { residue }\end{array}$ & $\begin{array}{c}8.18 \\
(66.37)\end{array}$ & $\begin{array}{c}7.93 \\
(62.35)\end{array}$ & $\begin{array}{c}10.04 \\
(100.40)\end{array}$ & $\begin{array}{c}93.59 \\
(91.43)\end{array}$ & $\begin{array}{c}4.34 \\
(18.38)\end{array}$ & $\begin{array}{c}4.13 \\
(16.56)\end{array}$ & $\begin{array}{c}4.81 \\
(22.65)\end{array}$ & $\begin{array}{c}4.55 \\
(20.16)\end{array}$ & 49.09 & 54.81 & 278.6 & 220.4 \\
\hline $\begin{array}{l}\text { Conventional } \\
\text { tillage-with } \\
\text { residue }\end{array}$ & $\begin{array}{c}7.03 \\
(48.87)\end{array}$ & $\begin{array}{c}6.85 \\
(46.86)\end{array}$ & $\begin{array}{c}8.35 \\
(69.23)\end{array}$ & $\begin{array}{c}7.99 \\
(63.38)\end{array}$ & $\begin{array}{c}4.18 \\
(16.99)\end{array}$ & $\begin{array}{c}3.98 \\
(15.32)\end{array}$ & $\begin{array}{c}4.39 \\
(18.78)\end{array}$ & $\begin{array}{c}4.15 \\
(16.72)\end{array}$ & 59.12 & 59.38 & 223.7 & 198.1 \\
\hline $\begin{array}{l}\text { Zero tillage- } \\
\text { no residue }\end{array}$ & $\begin{array}{c}7.89 \\
(61.69)\end{array}$ & $\begin{array}{c}7.65 \\
(58.00)\end{array}$ & $\begin{array}{c}9.79 \\
(95.30)\end{array}$ & $\begin{array}{c}9.34 \\
(86.78)\end{array}$ & $\begin{array}{c}4.29 \\
(17.94)\end{array}$ & $\begin{array}{c}4.08 \\
(16.17)\end{array}$ & $\begin{array}{c}4.65 \\
(21.10)\end{array}$ & $\begin{array}{c}4.39 \\
(18.78)\end{array}$ & 52.07 & 57.56 & 262.3 & 207.0 \\
\hline $\begin{array}{l}\text { Zero tillage- } \\
\text { with residue }\end{array}$ & $\begin{array}{c}6.73 \\
(44.76)\end{array}$ & $\begin{array}{c}6.40 \\
(40.85)\end{array}$ & $\begin{array}{c}7.94 \\
(63.02)\end{array}$ & $\begin{array}{c}7.63 \\
(57.68)\end{array}$ & $\begin{array}{c}4.04 \\
(16.17)\end{array}$ & $\begin{array}{c}3.78 \\
(14.57)\end{array}$ & $\begin{array}{c}4.19 \\
(17.06)\end{array}$ & $\begin{array}{c}3.96 \\
(15.19)\end{array}$ & 62.37 & 62.46 & 205.9 & 183.1 \\
\hline SEm \pm & 0.09 & 0.14 & 0.13 & 0.12 & 0.04 & 0.06 & 0.06 & 0.05 & - & - & 7.63 & 6.05 \\
\hline $\mathrm{CD}(p=0.05)$ & 0.28 & 0.43 & 0.39 & 0.35 & 0.11 & 0.18 & 0.18 & 0.17 & - & - & 22.86 & 18.14 \\
\hline \multicolumn{13}{|c|}{ Weed management practices } \\
\hline Weedy check & $\begin{array}{c}9.68 \\
(93.62)\end{array}$ & $\begin{array}{c}9.55 \\
(90.74)\end{array}$ & $\begin{array}{c}13.17 \\
(173.12)\end{array}$ & $\begin{array}{c}12.64 \\
(159.22)\end{array}$ & $\begin{array}{c}6.09 \\
(36.56)\end{array}$ & $\begin{array}{c}5.78 \\
(32.95)\end{array}$ & $\begin{array}{c}6.71 \\
(44.47)\end{array}$ & $\begin{array}{c}6.33 \\
(39.58)\end{array}$ & 0.00 & 0.00 & 547.2 & 487.7 \\
\hline Weed free & $\begin{array}{c}0.71 \\
(0.00)\end{array}$ & $\begin{array}{c}0.71 \\
(0.00)\end{array}$ & $\begin{array}{c}0.71 \\
(0.00)\end{array}$ & $\begin{array}{c}0.71 \\
(0.00)\end{array}$ & $\begin{array}{c}0.71 \\
(0.00)\end{array}$ & $\begin{array}{c}0.71 \\
(0.00)\end{array}$ & $\begin{array}{c}0.71 \\
(0.00)\end{array}$ & $\begin{array}{c}0.71 \\
(0.00)\end{array}$ & 100.0 & 100.0 & 0.0 & 0.0 \\
\hline $\begin{array}{l}\text { Mesosulfuron } \\
\text { @ } 12 \mathrm{~g} \text { a.i. } \\
\text { ha }^{-1} \text { at } 30 \text { DAS } \\
\mathrm{fb} \text { one HW at } \\
45 \text { DAS }\end{array}$ & $\begin{array}{c}8.30 \\
(68.45)\end{array}$ & $\begin{array}{c}8.02 \\
(63.85)\end{array}$ & $\begin{array}{c}9.81 \\
(95.82)\end{array}$ & $\begin{array}{c}9.36 \\
(87.16)\end{array}$ & $\begin{array}{c}4.39 \\
(18.80)\end{array}$ & $\begin{array}{c}4.18 \\
(16.95)\end{array}$ & $\begin{array}{c}4.71 \\
(21.68)\end{array}$ & $\begin{array}{c}4.45 \\
(19.30)\end{array}$ & 51.68 & 55.42 & 264.4 & 217.4 \\
\hline $\begin{array}{l}\text { Metsulfuron } \\
\text { @ } 4 \mathrm{~g} \text { a.i. ha }{ }^{-1} \\
\text { at } 30 \text { DAS } f b \\
\text { one HW at } 45 \\
\text { DAS }\end{array}$ & $\begin{array}{c}8.09 \\
(64.90)\end{array}$ & $\begin{array}{c}7.82 \\
(60.58)\end{array}$ & $\begin{array}{c}9.55 \\
(90.69)\end{array}$ & $\begin{array}{c}9.11 \\
(82.50)\end{array}$ & $\begin{array}{c}4.32 \\
(18.17)\end{array}$ & $\begin{array}{c}4.11 \\
(16.38)\end{array}$ & $\begin{array}{c}4.63 \\
(20.97)\end{array}$ & $\begin{array}{c}4.38 \\
(18.67)\end{array}$ & 54.22 & 57.80 & 250.5 & 205.8 \\
\hline $\begin{array}{l}\text { Clodinafop+ } \\
\text { metsulfuron } \\
@ 60+4 \text { g a.i. } \\
\text { ha }^{-1} \text { at } 30 \text { DAS }\end{array}$ & $\begin{array}{c}7.39 \\
(54.58)\end{array}$ & $\begin{array}{c}7.16 \\
(51.16)\end{array}$ & $\begin{array}{c}8.31 \\
(69.02)\end{array}$ & $\begin{array}{c}7.88 \\
(62.07)\end{array}$ & $\begin{array}{c}3.97 \\
(15.73)\end{array}$ & $\begin{array}{c}3.83 \\
(14.18)\end{array}$ & $\begin{array}{c}4.12 \\
(16.51)\end{array}$ & $\begin{array}{c}3.90 \\
(14.70)\end{array}$ & 62.28 & 67.40 & 206.4 & 159.0 \\
\hline $\begin{array}{l}\text { Mesosulfu- } \\
\text { ron+iodo- } \\
\text { sulfuron @ } \\
12+2.4 \text { g a.i. } \\
\text { ha }^{-1} \text { at } 30 \text { DAS }\end{array}$ & $\begin{array}{c}7.14 \\
(50.96)\end{array}$ & $\begin{array}{c}6.80 \\
(45.74)\end{array}$ & $\begin{array}{c}7.96 \\
(63.33)\end{array}$ & $\begin{array}{c}7.58 \\
(57.98)\end{array}$ & $\begin{array}{c}3.90 \\
(14.96)\end{array}$ & $\begin{array}{c}3.74 \\
(13.48)\end{array}$ & $\begin{array}{c}4.03 \\
(15.74)\end{array}$ & $\begin{array}{c}3.81 \\
(14.01)\end{array}$ & 65.79 & 70.66 & 187.2 & 143.1 \\
\hline SEm \pm & 0.08 & 0.12 & 0.12 & 0.10 & 0.03 & 0.03 & 0.03 & 0.04 & - & - & 6.41 & 13.12 \\
\hline $\operatorname{CD}(p=0.05)$ & 0.26 & 0.37 & 0.35 & 0.31 & 0.08 & 0.10 & 0.10 & 0.11 & - & - & 19.23 & 16.11 \\
\hline
\end{tabular}

*Data given within parentheses are original values and that given outside are square root transformed values $\sqrt{ }(\mathrm{x}+0.5)$ 
methyl and clodinafop+metsulfuron (Singh et al., 2015). Brar and Walia (2009) reported sulfosulfuron @ $25 \mathrm{~g} \mathrm{ha}^{-1}$ and mesosulfuron+iodosulfuron @ $12 \mathrm{~g} \mathrm{ha}^{-1}$ recorded significantly lower density and dry weight of weed than clodinafop @ 60 $\mathrm{g} \mathrm{ha}^{-1}$ alone and clodinafop @ $60 \mathrm{~g} \mathrm{ha}^{-1} \mathrm{fb}$ 2, 4-D $0.5 \mathrm{~kg} \mathrm{ha}^{-1}$ treatments.

\subsection{Weed control efficiency (WCE)}

Among crop establishment methods, ZT with residue recorded highest weed control efficiency in both the years (Table 1). This was closely followed by CT with residue. However, ZT/CT without residue showed negative WCE in both the years, indicating that there may be problem of perennial and annual weeds in without residue application treatments as compared to ZT with residue and CT with residue treatments. The residue mulch suppressed the germination and growth of weeds and resulted in higher WCE (Verma et al., 2016). WCE was significantly highest with application of mesosulfuron+iodosulfuron followed by clodinafop+metsulfuron, metsulfuron $f b$ one hand weeding at 45 DAS and mesosulfuron $f b$ one hand weeding at 45 DAS, respectively. Application of mesosulfuron+iodosulfuron resulted in $65.79 \%$ WCE which was at par with clodinafop +metsulfuron (62.28\%) may be due to more control of grassy and broadleaf weeds. Highest WCE indicates its relative performance of particular set of treatment (Verma et al., 2015). Meena and Singh (2013) also reported higher WCE with tank-mix application of herbicides over their sole application.

\subsection{Nutrient depletion by weeds}

The weeds usually grow faster than associated crop plants and thus absorb the available nutrients in huge quantity and lead deficiency of nutrients to the crop plants (Table 5). Competition begins when the root system of crop and weeds overlap in the exploring soil profile and show the enhanced competition for nutrients. The minimum depletion of nutrients (NPK) by weeds was recorded under ZT with residue and maximum in CT no-residue. Weed management practices also significantly influenced the N, P and K depletion by weeds. Significantly the highest nutrients depletion was recorded under mesosulfuron $\mathrm{fb}$ one hand weeding at $45 \mathrm{DAS}$. The increase in the depletion of $\mathrm{N}, \mathrm{P}$ and $\mathrm{K}$ by weeds under this treatment was due to poor control of weeds resulted highest dry weight of weed, which is corroborated with the findings of Monsefi et al. (2016). Weeds infestation in wheat is rampant and cause depletion of $31 \mathrm{~kg}$ $\mathrm{N}, 16 \mathrm{~kg} \mathrm{P}$ and $29 \mathrm{~kg} \mathrm{~K} \mathrm{ha}^{-1}$ from wheat crop field. Besides, NPK depletion, the considerable amount of secondary and micro-nutrients also deplete, thereby resulting in heavy yield reduction (Pandey et al., 2007).

\subsection{Crop growth parameters}

The values of growth parameters viz. plant height, number of tillers, dry matter accumulation, leaf area index and chlorophyll content were highest under CT with residue as compared to ZT with residue, CT no-residue and ZT no-residue (Table 2). These results are corroborated with the findings of Sharma et al. (2009) and Singh et al. (2011). CT system recorded higher plants height with maximum dry matter accumulation, highest leaf area index and crop growth rate (CGR) followed by minimum and zero tillage system (Nayak et al., 2006). Among weed management practices, hand weeding (weed free) treatments performed better over rest of the herbicidal treatments as it recorded the maximum values for all the growth parameters. In herbicidal treatments, an application of mesosulfuron+iodosulfuron resulted highest plant population, plant height, number of tillers running meter ${ }^{-1}$, leaf area index and chlorophyll content of wheat followed by clodinafop+metsulfuron, metsulfuron $f b$ one hand weeding at 45 DAS and mesosulfuron $f b$ one hand weeding at 45 DAS, respectively. These results are in line with research findings of Tomar and Tomar (2014) and Monsefi et al. (2016).

\subsection{Grain and straw yield}

Grain and straw yield is an ultimate result of growth and yield components (Table 3 and 4). Crop establishment methods and weed management practices showed significant influence on yield of crop. CT with residue recorded significantly highest grain and straw yield than other crop establishment treatments. This was attributed due to production of higher yield attributing characters in CT with residue over rest of the treatments. These results are in conformity with research findings of Vyas et al. (2013); Sekhar et al. (2014), Upasani et al. (2014) and Sharma and Singh (2014). With respect to herbicidal treatments, significantly the highest grain and straw yield was recorded under mesosulfuron+iodosulfuron followed by clodinafop+metsulfuron, metsulfuron $f b$ one hand weeding at 45 DAS and mesosulfuron $f b$ one hand weeding at 45 DAS, respectively. These results are in agreement with the research findings of Singh et al. (2015). The lowest grain and straw yield was recorded in weedy check due to more weed growth and poor performance of yield attributing characters. Relative weed free situation under herbicidal treatments reduced the crop weed competition and thus lead to higher vegetative growth and yield attributes which significantly affected the grain and straw yield of wheat. Similar results were also reported by Tomar and Tomar (2014) and Monsefi et al. (2016). The interaction effect of crop establishment methods and weed management practices was also observed significant $(p=0.05)$ with respect to grain and straw yield in both the years. Mix application of mesosulfuron+iodosulfuron in combination with CT with residue recorded highest grain and straw yield and was statistically at par with clodinafop+metsulfuron and was significantly superior over the remaining treatment combinations.

\subsection{Nutrients uptake by crop}

Crop establishment methods and weed management practices significantly influenced the N, P and K uptake by wheat (Table 5). CT with residue recorded maximum uptake of $\mathrm{N}, \mathrm{P}$ and $\mathrm{K}$, whereas uptake was lower in $\mathrm{ZT}$ with residue, CT no-residue and ZT no-residue, respectively. It could be attributed to better growing conditions under $C T$ with residue treatment during growth and development of crop which helped in better utilization of nutrients, thereby resulting in highest yield and nutrient uptake. The results are in line 
Table 2: Crop growth parameters as influenced by crop establishment methods and weed management practices

\begin{tabular}{|c|c|c|c|c|c|c|c|c|c|c|}
\hline \multirow[t]{2}{*}{ Treatments } & \multicolumn{2}{|c|}{$\begin{array}{l}\text { Plant height } \\
(\mathrm{cm}) \text { at } 80 \\
\text { DAS }\end{array}$} & \multicolumn{2}{|c|}{$\begin{array}{c}\text { Tillers running } \\
\text { meter }^{-1} \text { at } 80 \\
\text { DAS }\end{array}$} & \multicolumn{2}{|c|}{$\begin{array}{l}\text { Crop dry weight } \\
\text { meter }^{-1} \text { row } \\
\text { length (g) at } 80 \\
\text { DAS }\end{array}$} & \multicolumn{2}{|c|}{$\begin{array}{c}\text { Leaf area } \\
\text { index at } 60 \\
\text { DAS }\end{array}$} & \multicolumn{2}{|c|}{$\begin{array}{l}\text { Chlorophyll } \\
\text { content } \\
\text { (SPAD value) } \\
\text { at } 60 \text { DAS }\end{array}$} \\
\hline & 2014 & 2015 & 2014 & 2015 & 2014 & 2015 & 2014 & 2015 & 2014 & 2015 \\
\hline \multicolumn{11}{|l|}{ Crop establishment methods } \\
\hline Conventional tillage-no residue & 83.6 & 87.5 & 101.3 & 104.3 & 170.8 & 184.5 & 1.49 & 1.52 & 39.3 & 40.1 \\
\hline Conventional tillage-with residue & 89.5 & 92.2 & 111.0 & 114.3 & 177.0 & 191.1 & 1.67 & 1.72 & 39.5 & 40.3 \\
\hline Zero tillage-no residue & 84.9 & 86.1 & 99.2 & 102.2 & 169.1 & 182.6 & 1.42 & 1.45 & 38.6 & 39.4 \\
\hline Zero tillage-with residue & 87.6 & 90.3 & 106.5 & 109.8 & 174.8 & 188.8 & 1.59 & 1.62 & 39.4 & 40.2 \\
\hline SEm \pm & 1.2 & 1.3 & 2.3 & 2.3 & 0.8 & 0.8 & 0.02 & 0.03 & 0.45 & 0.47 \\
\hline $\operatorname{CD}(p=0.05)$ & 4.2 & 4.4 & 6.8 & 7.0 & 2.7 & 2.9 & 0.06 & 0.08 & NS & NS \\
\hline \multicolumn{11}{|l|}{ Weed management practices } \\
\hline Weed free & 89.1 & 91.8 & 115.0 & 118.5 & 177.3 & 191.5 & 1.69 & 1.76 & 39.9 & 40.7 \\
\hline $\begin{array}{l}\text { Mesosulfuron @ } 12 \mathrm{~g} \text { a.i. ha }{ }^{-1} \text { at } 30 \text { DAS } \\
f b \text { one HW at } 45 \text { DAS }\end{array}$ & 86.1 & 88.7 & 100.6 & 103.6 & 172.1 & 185.8 & 1.51 & 1.55 & 39.0 & 39.8 \\
\hline $\begin{array}{l}\text { Metsulfuron @ } 4 \text { g a.i. ha }{ }^{-1} \text { at } 30 \text { DAS fb } \\
\text { one HW at } 45 \text { DAS }\end{array}$ & 86.7 & 89.4 & 103.1 & 106.2 & 172.8 & 186.5 & 1.54 & 1.58 & 38.9 & 39.7 \\
\hline $\begin{array}{l}\text { Clodinafop+metsulfuron @ 60+4 g a.i. } \\
\text { ha }^{-1} \text { at } 30 \text { DAS }\end{array}$ & 87.6 & 90.3 & 108.1 & 111.4 & 174.3 & 188.3 & 1.61 & 1.65 & 39.2 & 40.0 \\
\hline $\begin{array}{l}\text { Mesosulfuron+iodosulfuron @ 12+2.4 g } \\
\text { a.i. ha-1 at } 30 \text { DAS }\end{array}$ & 88.5 & 91.2 & 112.3 & 115.7 & 175.4 & 189.4 & 1.65 & 1.69 & 39.5 & 40.3 \\
\hline SEm \pm & 0.5 & 0.5 & 1.1 & 1.1 & 0.5 & 0.6 & 0.01 & 0.02 & 0.22 & 0.26 \\
\hline $\mathrm{CD}(p=0.05)$ & 1.4 & 1.5 & 3.4 & 3.5 & 1.5 & 1.6 & 0.04 & 0.06 & NS & NS \\
\hline \multicolumn{11}{|c|}{ Table 3: Interaction effect of crop establishment methods and weed management practices on grain yield $(\mathrm{kg}$ ha-1) of wheat } \\
\hline \multicolumn{2}{|l|}{ Treatments } & \multicolumn{8}{|c|}{ Crop establishment methods } & Mean \\
\hline \multicolumn{2}{|l|}{ Weed management practices } & \multicolumn{2}{|c|}{$\begin{array}{l}\text { Conventional } \\
\text { tillage-no } \\
\text { residue }\end{array}$} & \multicolumn{2}{|c|}{$\begin{array}{l}\text { Conventional } \\
\text { tillage-with } \\
\text { residue }\end{array}$} & $\begin{array}{l}\text { Zero tillag } \\
\text { no residu }\end{array}$ & & \multicolumn{2}{|c|}{$\begin{array}{l}\text { Zero tillage- } \\
\text { with residue }\end{array}$} & \\
\hline \multicolumn{11}{|l|}{2014} \\
\hline \multicolumn{2}{|l|}{ Weedy check } & \multicolumn{2}{|c|}{1723} & \multicolumn{2}{|c|}{2036} & \multicolumn{2}{|l|}{1752} & \multicolumn{2}{|c|}{1930} & 1837 \\
\hline \multicolumn{2}{|l|}{ Weed free } & \multicolumn{2}{|c|}{3267} & \multicolumn{2}{|c|}{3477} & \multicolumn{2}{|l|}{3102} & \multicolumn{2}{|c|}{3340} & 3282 \\
\hline \multicolumn{2}{|c|}{$\begin{array}{l}\text { Mesosulfuron } 12 \mathrm{~g} \text { a.i. ha-1 } \mathrm{fb}^{-} \text {one hand weeding } \\
\text { at } 45 \text { DAS }\end{array}$} & \multicolumn{2}{|c|}{2718} & \multicolumn{2}{|c|}{2750} & 2589 & & 2658 & & 2685 \\
\hline $\begin{array}{l}\text { Metsulfuron @ } 4 \text { g a.i. ha } f b \text { one hand we } \\
\text { at } 45 \text { DAS }\end{array}$ & & 278 & & 277 & & 2638 & & 2677 & & 2730 \\
\hline Clodinafop+metsulfuron @ 60+4 g a.i. ha & & 292 & & 326 & & 2885 & & 3080 & & 3028 \\
\hline $\begin{array}{l}\text { Mesosulfuron+iodosulfuron @12+2.4 } \\
\text { ha }^{-1}\end{array}$ & a.i. & 295 & & 332 & & 2929 & & 3159 & & 3069 \\
\hline Mean & & 272 & & 293 & & 2649 & & 2807 & & \\
\hline SEm \pm & & & & 41.6 & & & & & & \\
\hline $\operatorname{CD}(p=0.05)$ & & & & 118. & & & & & & \\
\hline
\end{tabular}




\begin{tabular}{|c|c|c|c|c|c|}
\hline \multirow{2}{*}{$\begin{array}{l}\text { Treatments } \\
\text { Weed management practices }\end{array}$} & \multicolumn{4}{|c|}{ Crop establishment methods } & \multirow[t]{2}{*}{ Mean } \\
\hline & $\begin{array}{l}\text { Conventional till- } \\
\text { age no residue }\end{array}$ & $\begin{array}{l}\text { Conventional till- } \\
\text { age with residue }\end{array}$ & $\begin{array}{l}\text { Zero tillag } \\
\text { no residue }\end{array}$ & $\begin{array}{l}\text { Zero tillag } \\
\text { with residue }\end{array}$ & \\
\hline \multicolumn{6}{|l|}{2015} \\
\hline Weedy check & 2798 & 2834 & 2694 & 2793 & 2776 \\
\hline Weed free & 4960 & 5223 & 4940 & 5050 & 5041 \\
\hline $\begin{array}{l}\text { Mesosulfuron } 12 \mathrm{~g} \text { a.i. ha }{ }^{-1} \mathrm{fb} \text { one hand } \\
\text { weeding at } 45 \text { DAS }\end{array}$ & 4172 & 4204 & 3934 & 4078 & 4104 \\
\hline $\begin{array}{l}\text { Metsulfuron @ } 4 \mathrm{~g} \text { a.i. ha } \mathrm{fb} \text { one hand } \\
\text { weeding at } 45 \text { DAS }\end{array}$ & 4132 & 4211 & 4039 & 4077 & 4127 \\
\hline Clodinafop+metsulfuron @ 60+4 g a.i. ha-1 & 4429 & 4943 & 4379 & 4757 & 4584 \\
\hline $\begin{array}{l}\text { Mesosulfuron+iodosulfuron @ 12+2.4 g } \\
\text { a.i. ha-1 }\end{array}$ & 4482 & 4957 & 4478 & 4902 & 4639 \\
\hline Mean & 4162 & 4395 & 4078 & 4276 & \\
\hline SEm \pm & & 40.16 & & & \\
\hline $\mathrm{CD}(p=0.05)$ & & 114.78 & & & \\
\hline
\end{tabular}

Table 4: Interaction effect of crop establishment methods and weed management practices on straw yield $\left(\mathrm{kg}^{\mathrm{k}} \mathrm{h}^{-1}\right)$ of wheat

\begin{tabular}{|c|c|c|c|c|c|}
\hline \multirow{2}{*}{$\begin{array}{l}\text { Treatments } \\
\text { Weed management practices }\end{array}$} & \multicolumn{4}{|c|}{ Crop establishment methods } & \multirow[t]{2}{*}{ Mean } \\
\hline & CTNR & CTAWR & $\begin{array}{l}\text { Zero tillage- } \\
\text { no residue }\end{array}$ & $\begin{array}{l}\text { Zero tillage- } \\
\text { with residue }\end{array}$ & \\
\hline \multicolumn{6}{|l|}{2014} \\
\hline Weedy check & 2805 & 3470 & 2837 & 3258 & 3037 \\
\hline Weed free & 4821 & 5057 & 4697 & 4999 & 4858 \\
\hline Mesosulfuron $12 \mathrm{~g}$ a.i. ha-1 $\mathrm{fb}$ one hand weeding at 45 DAS & 4481 & 4600 & 4337 & 4505 & 4473 \\
\hline Metsulfuron @ 4 g a.i. ha $f b$ one hand weeding at 45 DAS & 4507 & 4655 & 4427 & 4523 & 4530 \\
\hline Clodinafop+ metsulfuron @ 60+4 g a.i. ha-1 & 4594 & 4661 & 4445 & 4639 & 4567 \\
\hline Mesosulfuron+iodosulfuron @ 12+2.4 g a.i. ha-1 & 4644 & 4715 & 4487 & 4692 & 4615 \\
\hline Mean & 4309 & 4526 & 4205 & 4436 & \\
\hline SEm \pm & & 43.71 & & & \\
\hline $\operatorname{CD}(p=0.05)$ & & 124.92 & & & \\
\hline \multicolumn{6}{|l|}{2015} \\
\hline Weedy check & 4029 & 4222 & 3935 & 4209 & 4062 \\
\hline Weed free & 6972 & 7143 & 6949 & 7064 & 7021 \\
\hline Mesosulfuron $12 \mathrm{~g}$ a.i. ha ${ }^{-1} \mathrm{fb}$ one hand weeding at 45 DAS & 6100 & 6171 & 5815 & 6006 & 6029 \\
\hline $\begin{array}{l}\text { Metsulfuron @ } 4 \text { g a.i. ha } f b \text { one hand weeding at } \\
45 \text { DAS }\end{array}$ & 6079 & 6250 & 5934 & 6054 & 6087 \\
\hline Clodinafop+metsulfuron @ 60+4 g a.i. ha-1 & 6354 & 7038 & 6133 & 6586 & 6509 \\
\hline Mesosulfuron+iodosulfuron @ 12+2.4 g a.i. ha-1 & 6353 & 7115 & 6238 & 6584 & 6569 \\
\hline Mean & 5981 & 6323 & 5834 & 6084 & \\
\hline SEm \pm & & 66.83 & & & \\
\hline $\operatorname{CD}(p=0.05)$ & & 191.02 & & & \\
\hline
\end{tabular}

CTNR: Conventional tillage no residue; CTAWR: Conventional tillage with residue 
Table 5: Effect of crop establishment methods and weed management practices on NPK depletion by weeds and their uptake by wheat crop

\begin{tabular}{|c|c|c|c|c|c|c|c|c|c|c|c|c|}
\hline \multirow[t]{3}{*}{ Treatments } & \multicolumn{6}{|c|}{ Nutrients depletion by weeds $\left(\mathrm{kg} \mathrm{ha}^{-1}\right)$} & \multicolumn{6}{|c|}{ Nutrients uptake by crop $\left(\mathrm{kg} \mathrm{ha}^{-1}\right)$} \\
\hline & \multicolumn{2}{|c|}{$\mathrm{N}$} & \multicolumn{2}{|c|}{$\mathrm{P}$} & \multicolumn{2}{|c|}{ K } & \multicolumn{2}{|c|}{$\mathrm{N}$} & \multicolumn{2}{|c|}{$P$} & \multicolumn{2}{|c|}{ K } \\
\hline & 2014 & 2015 & 2014 & 2015 & 2014 & 2015 & 2014 & 2015 & 2014 & 2015 & 2014 & 2015 \\
\hline \multicolumn{13}{|l|}{ Crop establishment methods } \\
\hline $\begin{array}{l}\text { Conventional tillage-no } \\
\text { residue }\end{array}$ & 5.21 & 0.89 & 5.51 & 4.03 & 0.69 & 4.30 & 68.3 & 100.3 & 15.1 & 22.0 & 84.8 & 118.6 \\
\hline $\begin{array}{l}\text { Conventional tillage-with } \\
\text { residue }\end{array}$ & 4.20 & 0.72 & 4.44 & 3.64 & 0.63 & 3.88 & 72.2 & 104.4 & 15.8 & 22.7 & 88.7 & 123.8 \\
\hline Zero tillage-no residue & 4.90 & 0.84 & 5.19 & 3.78 & 0.65 & 4.04 & 66.8 & 98.2 & 14.7 & 21.5 & 82.9 & 115.7 \\
\hline Zero tillage-with residue & 3.87 & 0.67 & 4.10 & 3.37 & 0.59 & 3.60 & 69.6 & 102.0 & 15.3 & 22.1 & 86.8 & 119.7 \\
\hline SEm \pm & 0.16 & 0.11 & 0.04 & 0.03 & 0.15 & 0.11 & 0.81 & 0.76 & 0.16 & 0.19 & 0.63 & 1.33 \\
\hline $\mathrm{CD}(p=0.05)$ & 0.49 & 0.11 & 0.44 & 0.32 & 0.08 & 0.34 & 2.41 & 2.27 & 0.48 & 0.56 & 1.87 & 3.96 \\
\hline \multicolumn{13}{|l|}{ Weed management practices } \\
\hline Weedy check & 10.07 & 1.65 & 10.57 & 8.77 & 1.45 & 9.31 & 45.92 & 65.54 & 9.88 & 14.09 & 58.29 & 78.83 \\
\hline Weed free & 0.00 & 0.00 & 0.00 & 0.00 & 0.00 & 0.00 & 83.03 & 119.03 & 18.66 & 26.67 & 100.46 & 139.68 \\
\hline $\begin{array}{l}\text { Mesosulfuron @ } 12 \text { g a.i. } \\
\text { ha }{ }^{-1} \text { at } 30 \text { DAS } f b \text { one HW } \\
\text { at } 45 \text { DAS }\end{array}$ & 4.95 & 0.84 & 5.23 & 3.98 & 0.68 & 4.25 & 67.5 & 98.5 & 15.2 & 21.8 & 87.2 & 118.8 \\
\hline $\begin{array}{l}\text { Metsulfuron @ } 4 \mathrm{~g} \text { a.i. ha }{ }^{-1} \\
\text { at } 30 \text { DAS } f b \text { one HW at } \\
45 \text { DAS }\end{array}$ & 4.70 & 0.80 & 4.96 & 3.77 & 0.65 & 4.03 & 69.3 & 101.0 & 15.4 & 22.0 & 88.2 & 119.6 \\
\hline $\begin{array}{l}\text { Clodinafop+metsulfuron } \\
@ 60+4 \text { g a.i. ha } a^{-1} \text { at } 30 \text { DAS }\end{array}$ & 3.88 & 0.67 & 4.11 & 2.92 & 0.51 & 3.12 & 75.0 & 109.9 & 16.2 & 23.6 & 90.4 & 128.5 \\
\hline $\begin{array}{l}\text { Mesosulfuron+ iodosulfu- } \\
\text { ron @ } 12+2.4 \mathrm{~g} \text { a.i. ha }{ }^{-1} \text { at } \\
30 \text { DAS }\end{array}$ & 3.52 & 0.61 & 3.73 & 2.63 & 0.46 & 2.82 & 75.7 & 110.8 & 16.3 & 23.7 & 91.1 & 129.3 \\
\hline SEm \pm & 0.12 & 0.10 & 0.03 & 0.02 & 0.13 & 0.10 & 0.71 & 0.66 & 0.11 & 0.14 & 0.56 & 0.86 \\
\hline $\mathrm{CD}(p=0.05)$ & 0.37 & 0.08 & 0.38 & 0.29 & 0.05 & 0.30 & 2.12 & 1.99 & 0.33 & 0.42 & 1.64 & 2.58 \\
\hline
\end{tabular}

with the findings of Pandey et al. (2008); Singh et al. (2011). Among weed management practices, mix application of mesosulfuron+iodosulfuron recorded highest uptake of $\mathrm{N}, \mathrm{P}$ and $\mathrm{K}$ by crop over metsulfuron $f b$ one hand weeding at 45 DAS and mesosulfuron $f b$ one hand weeding at 45 DAS and at par with clodinafop + metsulfuron. Significantly the highest nutrients uptake was recorded under weed free situation due to higher grain and straw yield of wheat. Higher NPK uptake by crops in weed free plots was also reported by Tomar and Tomar (2014); Monsefi et al. (2016). This was due to reduced depletion of nutrients by weeds and concomitant increase in the absorption and translocation of higher concentration of these nutrients to different wheat plant parts for enhanced photosynthetic efficiency, which corroborated with the findings of Bharat et al. (2012)

\section{Conclusion}

ZT with residue crop establishment method was more beneficial than other tested crop establishment methods as it recorded lowest weeds density and dry weight, nutrients depletion by weeds and highest WCE. However, CT with residue proved to be more advantageous for better crop growth parameters, yield, and nutrients uptake. Among herbicidal treatments, mix application of mesosulfuron+iodosulfuron was found to be superior over rest of the weed management practices as it significantly recorded lowest weeds density and dry weight and nutrients depletion by weeds and maximum WCE. Besides effective management of weeds, mix application of mesosulfuron+iodosulfuron also performed fairly with plant height, number of tillers running $\mathrm{m}^{-1}$, crop dry weight, LAI, chlorophyll content, yield and nutrients uptake.

\section{Acknowledgement}

The authors wish to thank Director, Institute of Agricultural Sciences, Banaras Hindu University for providing needed facilities for successful completion of research study. 


\section{References}

Bharat, R., Kachroo, D., Sharma, R., Gupta, M., Sharma, A.K., 2012. Effect of different herbicides on weed growth and yield performance of wheat. Indian Journal of Weed Science 44(2), 106-109.

Brar, A.S., Walia, U.S., 2009. Weed dynamics and wheat productivity as influenced by planting techniques and weed control practices. Indian Journal of Weed Science 41, 161-166.

Gomez, K.A., Gomez, A.A., 1984. Statistical Procedures for Agricultural Research, (2 ${ }^{\text {nd }}$ Edn.), John Willey and Sons Inc. New York, USA.

Jain, N., Mishra, J.S., Kewat, M.L., Jain, V., 2007. Effect of tillage and herbicides on grain yield and nutrient uptake by wheat and weeds. Indian Journal of Agronomy 52(2), 131-134.

Meena, B.L., Singh, R.K., 2013. Response of wheat to rice residue and weed management practices. Indian Journal of Agronomy 58(4), 521-524.

Mishra, J.S., Singh, V.P., Yaduraju, N.T., 2005. Effect of tillage practices and herbicides on weed dynamics and yield of wheat under transplanted rice-wheat system in Vertisol. Indian Journal of Agronomy 50(2), 106-109.

Monsefi, A., Sharma, A.R., Zan, N.R., 2016. Weed management and conservation tillage for improving productivity, nutrient uptake and profitability of wheat in soybeanwheat cropping system. International Journal of Plant Production 10(1), 1-12.

Nayak, M., Pradhan, A.C., Satapathy, M.R., Mohapatra, B.K., 2006. Soil properties, growth behaviour and yield of wheat in relation to weed management practices under different tillage systems. Annals Agricultural Research New Series 27(4), 315-321.

Pandey, I.B., Dwidedi, D.K., Pandey, R.K., 2007. Efficacy of herbicides and fertilizer management on weed dynamics in wheat. Indian Journal of Agronomy 52(1), 49-52.

Pandey, S.C., Singh, R.D., Saha, S., Singh, K.P., Prakash, V., Kumar, A., Kumar, M., Srivastava, A.K., 2008. Effect of tillage and irrigation on yield, profitability, water productivity and soil health in rice-wheat cropping system in north-west Himalayas. Indian Journal of Agricultural Sciences 78(12), 1018-1022.

Rao, A.N., Johnson, D.E., Sivaprasad, B., Ladha, J.K., Mortimer, A.M., 2007. Weed management in direct-seeded rice. Advances in Agronomy 93,153-255.

Sharma, A.R., Singh, V.P., 2014. Integrated weed management in conservation agriculture systems. Indian Journal of Weed Science 46(1), 23-30.

Sharma, P., Abrol, V., Sankar, G.R.M., Singh, B., 2009. Influence of tillage practices and mulching options on productivity, economics and soil physical properties of maize-wheat system. Indian Journal of Agricultural Sciences 79(11), 865-870.

Sharma, S.N., Singh, R.K., 2011. Productivity and economics of wheat as influenced by weed management and seed rate. Progressive Agriculture 11, 242-250.
Shekhar, C., Singh, D.A., Singh, K., Nepalia, V., Choudhary, J., 2014. Weed dynamics, productivity and soil health under different tillage and weed-control practices in wheat-maize cropping sequence. Indian Journal of Agronomy 59(4), 561-567.

Shyam, R., Singh, R., Singh, V.K., 2014. Effect of tillage and weed management practices on weed dynamics, weed seed bank and grain yield of wheat in rice-wheat system. Indian Journal of Weed Science 46(4), 322-325.

Singh, A.P., Makhan, S.B., Yadav, R., Chowdhury, T., 2015. Weed management in zero-till wheat. Indian Journal of Weed Science 47(3), 233-239.

Singh, B., Humphreys, E., Eberbach, P.L., Katupitiya, A., Singh, Y., Kukal, S.S., 2011. Growth, yield and water productivity of zero-till wheat as affected by rice straw mulch and irrigation schedule. Field Crops Research 121(2), 209-225.

Singh, P., Sarathambal, C., Kewat, M.L., Singh, V.P., 2015. Conservation tillage and weed management effect on soil micro flora of soybean-wheat cropping system. Indian Journal of Weed Science 47(4), 366-370.

Singh, R., Sharma, A.R., Dhyani, S.K., Dube, R.K., 2011. Tillage and mulching effects on performance of maize-wheat cropping system under varying land slopes. Indian Journal of Agricultural Sciences 81(4), 330-335.

Singh, R., Singh, A.P., Chaturvedi, S., Pal, R., Pal, J., 2015. Control of complex weed flora in wheat by metribuzin + clodinafop application. Indian Journal of Weed Science 47(1), 21-24.

Singh, S., 2007. Role of management practices on control of isoproturon-resistant littleseed canarygrass (Phalaris minor) in India. Weed Technology 21, 339-346.

Tomar, S.K., Tomar, T.S., 2014. Effect of herbicides and their tank mixture on weed dynamics and yield of zero-tilled wheat under rice-wheat cropping system of eastern Uttar Pradesh. Indian Journal of Agronomy 59(4), 624-628.

Upasani, R.R., Sheela, B., Singh, M.K., 2014. Tillage and weed management in direct-seeded rice-wheat cropping system. Indian Journal of Agronomy 59(2), 204-208.

Verma, S.K., Kumar, R., Singh, S.B., Meena, R.S., Prasad, S.K., Gaurav., 2016. Weed dynamics in greengram as influenced by mulching and weed management practices under eight year old Custard apple plantation in agrihorticultural system. American Journal of Experimental Agriculture 11(3), 1-13.

Verma, S.K., Singh, S.B., Prasad, S.K., Meena, R.N., Meena, R.S., 2015. Influence of irrigation regimes and weed management practices on water use and nutrient uptake in wheat. Bangladesh Journal of Botany 44(3), 437-442.

Vyas, A.K., Meena, H., Ramesh, A., Billore, S.D., Pandya, N., Khan, I.R., 2013. Influence of crop rotation and tillage systems on soil properties and productivity of soybean and wheat in Malwa region of Central India. Annals of Agricultural Research New Series 34(1), 44-49.

Yadav, N.S., Dixit, A., 2014. Bio efficacy of some herbicides and their mixtures against complex weed flora in wheat. Indian Journal of Weed Science 46(2), 180-183. 